\title{
ANALISIS IMPLEMENTASI KEBIJAKAN KETERBUKAAN INFORMASI PUBLIK DI KOMISI PENGAWAS PERSAINGAN USAHA REPUBLIK INDONESIA
}

\author{
Yogi Sumarsono Wibowo ${ }^{1}$, Gabriella Susilowati ${ }^{2}$, Riant Nugroho ${ }^{3}$ \\ Komisi Pengawas Persaingan Usaha RI ${ }^{1}$ \\ Pusat Sosial Ekonomi dan Kebijakan Pertanian Kementerian Pertanian ${ }^{2}$ \\ Rumah Reformasi Kebijakan ${ }^{3}$ \\ s.wibowo2010@gmail.com,yez.kinanti@yahoo.com, \\ yayasanrumahreformasi@gmail.com
}

Received: 09-06-2021

Revised : 11-07-2021

Accepted: 27-07-2021

\begin{abstract}
Abstrak
Latar Belakang: Lahirnya Undang-Undang No. 14 Tahun 2008 tentang Keterbukaan Informasi Publik (KIP) merupakan momentum sejarah bagi perwujudan berdemokrasi di Indonesia, sejarah panjang di Indonesia menunjukkan bahwa periode sebelum reformasi tahun 1998 untuk mengakses informasi publik merupakan suatu barang yang mewah untuk mendapatkannya.

Tujuan: Penelitian ini memberikan gambaran tentang bagaimana implementasi keterbukaan publik di Komisi Pengawas Persaingan Usaha (KPPU), yang lahir berdasarkan Undang-Undang Nomor 5 Tahun 1999, yang merupakan lembaga yang dilahirkan di era reformasi.
\end{abstract}

Metode: Penelitian ini menggunakan metode penelitian deskriptif yaitu prosedur pemecahan masalah yang diselidiki dengan menggambarkan keadaan subjek/objek penelitian pada saat sekarang berdasarkan fakta yang tampak.

Hasil: Lembaga KPPU merupakan jawaban dari tuntutan demokrasi ekonomi tahun 1989. Sebagai Badan Publik (BP), KPPU mempunyai kewajiban menjalankan Undang-Undang KIP. Sepanjang perjalanan KPPU RI selama 20 tahun, banyak informasi yang harus diketahui oleh masyarakat sebagai pemegang demokrasi, yang salah satunya adalah demokrasi mendapatkan hak akses informasi.

Kesimpulan: Penelitian ini menyimpulkan bahwa implementasi keterbukaan publik di KPPU sudah cukup baik dari aspek kelembagaan maupun substansi. Meskipun dalam hal implementasi belum memenuhi harapan publik, namun KPPU berupaya keras untuk mewujudkan praktek keterbukaan informasi publik. Penelitian ini diperkirakan memberikan manfaat dalam perkembangan implementasi keterbukaan publik di Indonesia, sehingga perlu mendapatkan perhatian dari Badan Publik agar kepercayaan publik lebih baik lagi.

Kata kunci: KPPU RI, keterbukaan informasi publik, implementasi kebijakan publik. 


\begin{abstract}
Background: The birth of Law no. 14 of 2008 concerning Openness of Public Information (KIP) is a historical momentum for the realization of democracy in Indonesia, Indonesia's long history shows that the period before the 1998 reformation to access public information was a luxury to obtain.

Objective: This study provides an overview of how the implementation of public disclosure in the Business Competition Supervisory Commission (KPPU), which was born based on Law Number 5 of 1999, is an institution that was born in the reform era.

Methods: This study uses descriptive research methods, namely problem solving procedures investigated by describing the current state of the subject/object of research based on visible facts.
\end{abstract}

Results: The KPPU institution is the answer to the demands of economic democracy in 1989. As a Public Agency (BP), $K P P U$ has the obligation to implement the KIP Law. Throughout the 20-year journey of KPPU RI, there is a lot of information that must be known by the public as the holder of democracy, one of which is that democracy has the right to access information.

Conslusion: This study concludes that the implementation of public disclosure at KPPU is sufficient, both in terms of institutional and substance. Although in terms of implementation, it has not met public expectations, KPPU strives to realize the practice of public information disclosure. This research is expected to provide benefits in the development of the implementation of public disclosure in Indonesia, so it needs to get attention from the Public Agency so that public trust is even better.

Keywords: KPPU RI, public information disclosure, public policy implementation.

Coresponden Author : Yogi Sumarsono Wibowo Email : s.wibowo2010@gmail.com

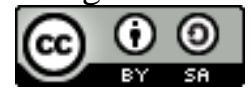

\title{
PENDAHULUAN
}

Demokrasi adalah suatu nilai universal yang telah diakui oleh seluruh negara di dunia. Salah satu hak dalam berdemokrasi adalah hak setiap warga negara mendapatkan kebebasan informasi. Kebebasan mendapatkan informasi sudah dinyatakan dalam Resolusi 59 (1) Majelis Umum PBB pada tahun 1946, yang menyatakan bahwa hak kebebasan informasi merupakan hak fundamental dan tanda dari seluruh kebebasan yang akan menjadi titik perhatian PBB dan diakui dalam pasal 19 Deklarasi Universal HAM PBB. Implementasi deklarasi HAM PBB tersebut diperkuat dengan pengakuan atas hak informasi dengan perubahan kedua Undang-Undang Negara Republik Indonesia Tahun 1945 pasal 29 F. Menurut (Maddox, 2007) terdapat dua aspek penting yang berhubungan dengan hak untuk informasi tanpa larangan-larangan dan hak untuk menerima informasi 
secara terbuka dan tanpa pembatasan-pembatasan. Kedua aspek hak untuk informasi ini bersifat timbal balik dan saling memengaruhi (pelaksanaan yang tergantung pada pelaksanaan yang lain.

Lahirnya demokrasi pasca reformasi tahun 1989, hak informasi mendapatkan tempat melalui Undang-Undang Keterbukaan Informasi Publik No. 14 Tahun 2008 yang ditandatangani pada tanggal 30 April 2008. Undang-Undang ini memberikan kewajiban kepada setiap Badan Publik (BP) untuk membuka akses bagi setiap pemohon informasi publik untuk mendapatkan informasi publik, dengan pengecualian beberapa informasi tertentu. Undang-Undang ini juga dimaksudkan sebagai instrumen pengembangan pribadi setiap insan dengan lingkungan sosialnya serta merupakan bagian penting bagi ketahanan nasional. Setiap warga negara mempunyai hak untuk memperoleh informasi yang merupakan hak asasi manusia. Keterbukaan informasi publik merupakan salah satu ciri penting negara demokratis yang menjunjung tinggi kedaulatan rakyat untuk mewujudkan penyelenggaraan negara yang baik. Keterbukaan informasi publik merupakan sarana dalam mengoptimalkan pengawasan publik terhadap penyelenggaraan negara dan BP lainnya dan segala sesuatu yang berakibat pada kepentingan publik dan pengelolaan informasi publik merupakan salah satu upaya untuk mengembangkan warga masyarakat informasi.

Tujuan keterbukaan informasi publik yaitu: menjamin hak warga negara untuk mengetahui rencana pembuatan kebijakan publik, program kebijakan publik, dan proses pengambilan keputusan publik, serta alasan pengambilan suatu keputusan publik; mendorong partisipasi masyarakat dalam proses pengambilan kebijakan publik; meningkatkan peran aktif masyarakat dalam pengambilan kebijakan publik dan pengelolaan BP yang baik; mewujudkan penyelenggaraan negara yang baik, yaitu yang transparan, efektif dan efisien, akuntabel serta dapat dipertanggungjawabkan; mengetahui alasan kebijakan publik yang memengaruhi hajat hidup orang banyak; mengembangkan ilmu pengetahuan dan mencerdaskan kehidupan bangsa; dan/atau meningkatkan pengelolaan dan pelayanan informasi di lingkungan BP untuk menghasilkan layanan informasi yang berkualitas.

Wakil Presiden K.H. Ma'ruf Amin pada tanggal 28 September 2020 dalam Diskusi Publik Peringatan Hari Hak Sedunia menyampaikan:

"Keterbukaan informasi publik merupakan ruh demokrasi yang menetapkan kewajiban transparansi dan akuntabilitas pada badan publik, sekaligus membuka saluran partisipasi masyarakat dalam setiap perumusan dan pelaksanaan program pembangunan. Oleh karena itu, Wapres menegaskan bahwa keterbukaan informasi publik merupakan salah satu komitmen pemerintah Indonesia dalam melaksanakan pembangunan nasional. Terwujudnya keterbukaan informasi di seluruh badan publik merupakan elemen penting dalam penyelenggaraan pemerintahan yang baik dan bersih".

Keterbukaan informasi merupakan salah satu bentuk partisipasi masyarakat dalam mendapatkan saluran informasi pembuat kebijakan yang diamanatkan oleh Undang-Undang Dasar Negara Republik Indonesia Tahun 1945, dijelaskan oleh Wapres sebagai berikut:

"Hal ini selaras dengan amanat Undang-Undang Dasar Negara Republik Indonesia Tahun 1945, yang juga telah memberikan jaminan bagi seluruh warga negara untuk berkomunikasi dan mencari, memperoleh, memiliki, menyimpan, mengolah, serta menyampaikan informasi dengan menggunakan segala jenis saluran yang tersedia. Sesuai mandat Ayat 3 Pasal 28 D UUD 1945, setiap warga negara berhak memperoleh kesempatan yang sama dalam pemerintahan”.

Implementasi keterbukaan informasi masih belum maksimal dilaksanakan oleh BP, meskipun kepatuhan pelaksanaan Undang Undang ini sudah dilaksanakan sejak 2010. Masih perlu penguatan daya juang yang maksimal untuk menjadikan keterbukaan informasi. Berdasarkan data dari hasil monitoring dan evaluasi yang disampaikan oleh 
Ketua KIP hasil monev keterbukaan BP, bahwa dari 348 BP yang dimonitor sepanjang tahun 2020, mayoritas masih Sangat Rendah kepatuhan dalam melaksanakan keterbukaan informasi publik yaitu 72,99 persen $(254 \mathrm{BP}), 17,53$ persen (61 BP) hanya masuk katergori Cukup Informatif, 13,51 persen (47 BP) Kurang Informatif dan 41,95 persen (146 BP) Tidak Informatif.

Kategori BP Informatif hanya 17,43 persen (60 BP) dan Menuju Informatif 9,77 persen (34 BP) yang dapat dinilai telah melaksanakan UU Nomor 14 Tahun 2008 tentang keterbukaan Informasi Publik. Disampaikannya nilai setiap kategori, yaitu Informatif bernilai 90-100, Menuju Informatif 80-89,9, sedangkan Cukup Informatif hanya bernilai 60-79,9 (termasuk rendah keterbukaan informasinya), Kurang Informatif (40-59,9), dan Tidak Informatif (0-39,9), ternyata masih ada BP bernilai dibawah 10 bahkan 0 . Besarnya prosentase BP yang masih masuk kategori Cukup Informatif, Kurang Informatif bahkan Tidak Informatif masih memprihatinkan, maka harus digarisbawahi bahwa Keterbukaan Informasi Publik di Indonesia masih jauh dari tujuan yang diamanatkan oleh UU KIP.

Penjelasan di atas, menunjukkan praktek keterbukaan informasi di Indonesia masih belum berjalan dengan baik, demokrasi dan komunikasi yang diharapkan oleh reformasi bangsa Indonesia 1998 masih perlu diperjuangkan karena masih belum adanya komitmen dan perhatian dari BP yang memegang amanah dari rakyat. BP yang menjadi tulang punggung reformasi belum berjalan dengan baik. Proses perwujudan keterbukaan informasi publik cenderung dipengaruhi oleh seberapa besar kemauan dan komitmen dari pemegang otoritas dan penyedia informasi publik (Pratikno, 2012).

Sebagai salah satu lembaga non struktural, KPPU dibentuk berdasarkan Undang - Undang No. 5 Tahun 1999 tentang Larangan Praktik Monopoli dan Persaingan Usaha Tidak Sehat. Azas dari UU No 5 Tahun 1999, lahir sebagai produk reformasi dalam mewujudkan demokrasi ekonomi dengan memperhatikan keseimbangan antar kepentingan pelaku usaha dan kepentingan umum. Undang-Undang ini memberikan mandat kepada KPPU untuk menjalankan tugas menegakkan hukum persaingan usaha. Selain itu, KPPU merupakan lembaga independen yang terlepas dari kekuasaan pemerintah maupun pihak- pihak lain yang terkait dengan masalah persaingan usaha. Selain mengawasi pelaksanaan UU No 5 Tahun 1999 tentang larangan praktik monopoli dan persaingan usaha tidak sehat, berdasarkan UU no. 20 Tahun 2008 tentang Usaha Mikro, Kecil dan Menengah juncto Peraturan Pemerintah RI Nomor 17 Tahun 2013 tentang pelaksanaan Undang-Undang Nomor 20 Tahun 2008 tentang UMKM, KPPU juga diberikan kewenangan untuk mengawasi kemitraan.

Dalam menjalankan tugas dan fungsinya, Kelembagaan KPPU terdiri dari 9 komisioner dan dibantu oleh Sekretariat Jenderal, Deputi Pencegahan, dan Deputi Penegakan Hukum sebagai dukungan dalam menegakkan persaingan usaha yang sehat. Kinerja KPPU dari tahun 2002 sampai tahun 2020 telah menangani perkara sebanyak sebesar 423 perkara dengan tren perkara seperti dalam Grafik 1 di bawah ini.

Grafik 1. Tren Tahunan Perkara 


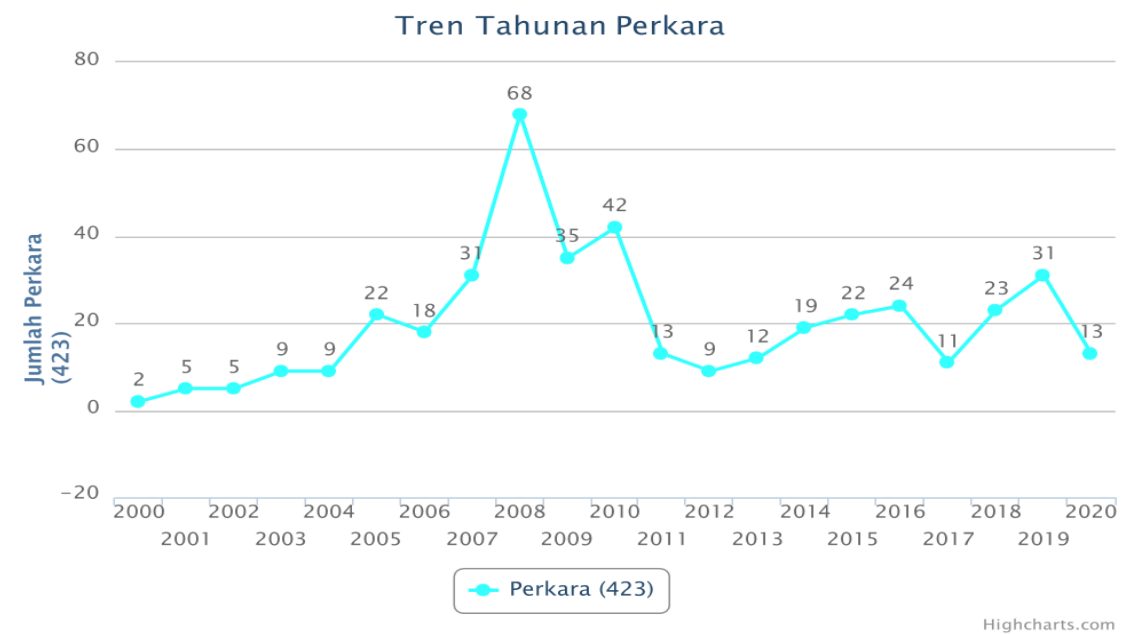

Sumber : Panitera KPPU, 2020

Dilihat dari perkara yang masuk, dapat dibedakan menjadi tender dan non tender dengan jumlah 273 perkara tender dan 150 perkara non tender, seperti pada Grafik 2 di bawah ini.

\section{Grafik 2. Perbandingan Perkara}

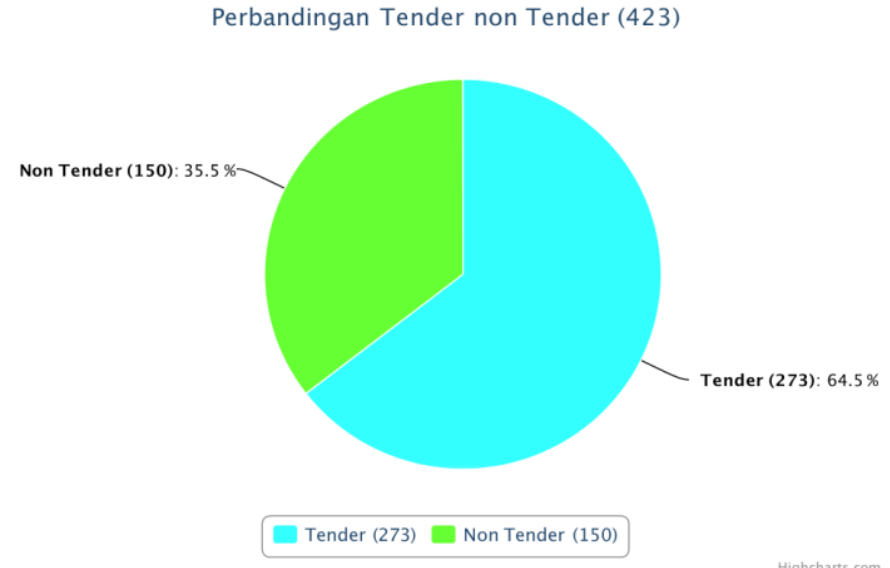

KPPU sebagai Badan Publik wajib mendukung Undang Undang Keterbukaan Publik dengan komitmen yang kuat dari Pimpinan dan Sekretariat KPPU. Implementasi Undang Undang Keterbukaan Pulik membuahkan hasil yaitu KPPU pernah mendapatkan penghargaan dari KIP dalam Kategori Keterbukaaan Informasi Badan Publik Tahun 2019 sebagai Kategori Lembaga Non Struktural sebagai Cukup Informatif dalam Implementasi UU No 14 Tahun 2008 yang diberikan pada tanggal 21 November 2019 dan di tahun 2020 (65,07\%). Pada tahun sebelumnya diberikan penganugerahan KPI sebagai Peringkat V Kategori LNS pada tanggal 15 Desember 2015. Hasil penilaian implementasi UU Keterbukaan Publik masih belum memenuhi harapan pemangku kepentingan di lingkungan internal, namun KPPU berkomitmen untuk meningkatkan kinerja keterbukaan informasi.

Perjalanan dan pengalaman selama kurang lebih 10 tahun implementasi UU KIP tersebut sejak ditetapkan pada tahun 2008 lalu tentu perlu dipelajari dan dikaji lebih mendalam lagi dengan ruang lingkup pada Implementasi Kebijakan Keterbukaan Informasi Publik di Komisi Pengawas Persaingan Usaha. 
Berdasarkan penjelasan di atas, maka permasalahan dalam penelitian ini dapat dirumuskan "Bagaimana Implementasi Kebijakan Keterbukaan Informasi di Komisi Pengawas Persaingan Usaha (KPPU) RI".

\section{METODE PENELITIAN}

Penelitian ini merupakan penelitian deskriptif yaitu prosedur pemecahan masalah yang diselidiki dengan menggambarkan keadaan subjek/objek penelitian pada saat sekarang berdasarkan fakta yang tampak. Populasi dan sampel sasaran pada penelitian ini adalah seluruh komponen (implementator) yang terlibat dalam implementasi kebijakan pusat informasi publik pada Komisi Pengawas Persaingan Usaha RI, yang terdiri dari pejabat dan staf Bagian Humas. untuk mengetahui bagaimana proses implementasi kebijakan keterbukaan informasi publik pada Komisi Pengawas Persaingan Usaha, dilihat dari pengembangan kelembagaan dan pencapaian substantif. Aspek substantif ini tersusun atas tiga indikator, yakni ketersediaan media penyampai, produk dan jenis informasi yang sudah dipublikasikan, dan kemudahan akses bagi publik untuk mendapatkan informasi tersebut.

Secara substantif kajian ini mempertimbangkan aspek capaian, kendala dan peluang yang terjadi selama implementasi kebijakan dilangsungkan. Dari gambaran tersebut dapat terpetakan problem utama implementasi, apakah berkaitan dengan masalah mendasar regulasi, desain kelembagaan penyelenggaraan, kapasitas aparat atau sumberdaya penyedia, ataukah sekadar teknis di lapangan. Selebihnya ragam inovasi dan terobosan positif yang berhasil dipotret memberi jejak pelajaran berharga yang memungkinkan direplikasi di daerah lain sesuai konteksnya.

\section{HASIL DAN PEMBAHASAN}

\section{A. Hasil Penelitian}

\section{Model Implementasi Publik di KPPU:}

Biro Humas dan Kerjasama telah merespon secara cepat keluarnya UndangUndang Nomor 14 Tahun 2008 tentang Keterbukaan Informasi Publik sejak tahun 2009, baik dengan mempertegas struktur kelembagaan Pejabat Pengelola Informasi dan Dokumentasi (PPID), meningkatkan ketersediaan jenis informasi serta memperluas aksesibilitasnya. Capaian keterbukaan informasi publik pada KPPU dianalisis dari dua indikator yaitu: kelembagaan dengan melihat dari pembentukan PPID; penetapan PPID; dan peraturan dan juknis terkait keterbukaan informasi publik dan substantif dengan melihat dari aspek media penyampai; produk dan jenis informasi yang disampaikan kepada publik; serta aspek kemudahan akses.

\section{Kelembagaan:}

Pada aspek kelembagaan, berdasarkan hasil penelitian menunjukkan bahwa KPPU telah memiliki PPID walaupun masih dalam tugas Biro Humas dan Kerjasama, yang merupakan lembaga mandiri yang berfungsi menjalankan UU Keterbukaan Informasi Publik. Sebagai BP pelaksana PPID, Biro Humas dan Kerjasama bertugas mengkoordinasikan pengumpulan seluruh informasi publik secara fisik dari setiap unit/satuan kerja yang meliputi: informasi yang wajib disediakan dan diumumkan secara berkala; informasi yang wajib tersedia setiap saat; informasi terbuka lainnya yang diminta pemohon informasi publik. Dalam rangka tanggungjawab, PPID dalam rangka membuat dan memutakhirkan Daftar Informasi Publik setelah dimutakhirkan oleh pimpinan 
masing-masing unit/satuan kerja, sekurang-kurangnya 1 (satu) kali dalam sebulan. Penyimpanan informasi publik telah dilaksanakan sesuai dengan peraturan perundangundangan dibidang kearsipan. Penyediaan dan pelayanan seluruh informasi publik merupakan tanggungjawab dan dikoordinasikan oleh Biro Humas dan Kerjasama yang dapat diakses oleh publik, dalam hal ini Bagian Hubungan Masyarakat. Dalam rangka tanggungjawab, PPID bertugas mengkoordinasikan penyediaan dan pelayanan Informasi Publik melalui pengumuman dan/atau permohonan. Dalam hal kewajiban mengumumkan informasi publik, bertugas untuk mengkoordinasikan: pengumuman informasi publik melalui media yang secara efektif dapat menjangkau seluruh pemangku kepentingan; dan penyampaian informasi publik dalam bahasa Indonesia yang baik dan benar. Setiap informasi publik harus dapat diperoleh setiap pemohon informasi publik dengan mekanisme yang cepat dan tepat waktu, biaya ringan dan cara sederhana.

\section{Substantif:}

Untuk menganalisis capaian keterbukaan informasi publik pada KPPU dilihat dari 3 indikator, yaitu media penyampai, produk dan jenis, serta kemudahan akses. Berdasarkan hasil penelitian menunjukkan bahwa media penyampai dalam implementasi keterbukaan informasi publik pada KPPU adalah melalui www.kppu.go.id. Namun demikian belum memiliki website tersendiri, dan direncanakan tahun 2021 akan dibentuk website tentang informasi publik KPPU yang terpisah.

\section{Ketersediaan media penyampai:}

Media penyampai informasi publik saat ini menggunakan media website kppu.go.id, apalagi di tengah kondisi pandemi virus corona, diusahakan seminimal mungkin media menggunakan tatap muka. Sesuai dengan informasi yang dipublikasikan melalui website tersebut dapat dilakukan dengan surat maupun email.

\section{Produk dan jenis informasi yang sudah dipublikasikan:}

Informasi yang disampaikan kepada pihak yang memerlukan terdiri dari daftar yang tidak dikecualikan yang terdiri dari dokumen administrasi seperti laporan keuangan dan sejenisnya yang dikeluarkan oleh Biro Perencanaan dan Keuangan, Laporan Kinerja masing-masing Unit Kerja dan KPPU RI secara keseluruhan secara berkala. Sedangkan dokumen yang terkait dengan tugas utama KPPU adalah Daftar Kajian terkait Persaingan Usaha, Hasil Kajian terkait Persaingan Usaha, Saran dan Pertimbangan terhadap kebijakan pemerintah yang berkaitan dengan praktik monopoli dan/atau persaingan usaha tidak sehat, Hasil Advokasi kepada Pemerintah/Regulator/pihak terkait Persaingan Usaha dan sejenisnya secara berkala.

\section{Kemudahan akses bagi publik untuk mendapatkan informasi:}

Akses bagi publik untuk mendapatkan informasi tersebut dapat dilakukan dengan datang langsung ke Kantor Pusat KPPU di Jalan Ir. H. Juanda No. 36 Jakarta Pusat, melalui surat atau via email dengan alur permohonan sebagai berikut: 


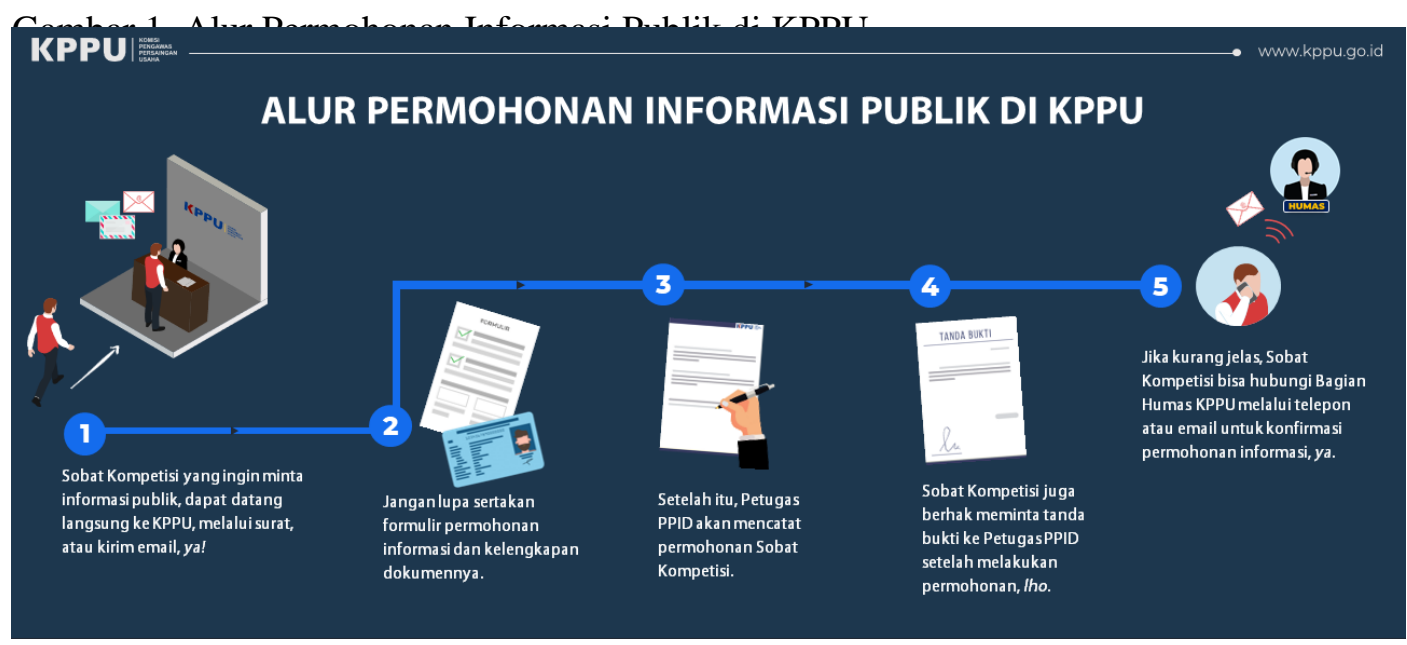

Sumber: KPPU, 2021 B. PEMBAHASAN

\section{B. Pembahasan}

\section{Keterbukaan Informasi Publik}

Pemerintah pada prinsipnya menjalankan tiga tugas utama, yaitu: menyelenggarakan pemerintahan, melaksanakan pembangunan, dan menyelenggarakan pelayanan publik. Pelayanan publik yang didasarkan pada keterbukaan informasi, akan mewujudkan suatu tata kelola pemerintahan yang baik. Berdasarkan data atau fakta empiris, pelayanan publik di Indonesia masih belum optimal. Kualitas pelayanan publik yang belum optimal, sebagaimana harapan masyarakat, akan mengurangi esensi tujuan pemerintah (negara) untuk mewujudkan kesejahteraan sosial bagi seluruh rakyat Indonesia (Wibawa, 2019).

Pelayanan publik yang baik dimulai dengan adanya keterbukaan informasi, namun kadang kala tidak semua pelayanan yang diberikan bersifa terbuka, sehingga informasi yang tertutup atau sikap tidak transparan tentu akan berdampak buruk bagi pemerintahan, terutama dalam hal pelayanan publik dan juga akan berdampak rendahnya kualitas pengetahuan masyarakat. Pengaruh transparansi secara parsial sangat berpengaruh terhadap kualitas pelayanan publik (Hermansyah et al., 2018). Jika informasi tertutup, maka pemerintahan dianggap otoriter atau pemerintahan yang berkuasa sendiri dan tidak demokratis. Hal ini menjadikan perlunya transparansi informasi, sehingga dapat tercipta keadilan yang menyeluruh bagi masyarakat.

Undang-Undang Nomor 14 Tahun 2008 atau dikenal dengan Undang-Undang Keterbukaan Informasi Publik merupakan undang-undang yang disahkan oleh pemerintah di tahun 2008. Undang-undang ini mewajibkan lembaga pemerintah untuk menyebarluaskan informasi yang harus diumumkan kepada publik atau masyarakat sebagai bentuk transparansi dalam hal pemenuhan informasi kepada pemohon informasi. Selain informasi yang boleh disebarkan kepada masyarakat tentunya ada juga informasi yang tidak boleh disebarkan, seperti informasi yang dapat merugikan negara, rahasia negara atau bahkan informasi yang mengancam persatuan dan kesatuan negara Republik Indonesia. Undang-Undang Keterbukaan Informasi Publik menjadi bagian penting dalam mengembangkan masyarakat yang sadar akan pentingnya keterbukaan informasi publik. Melalui undang-undang ini masyarakat dapat berpartisipasi dalam mengontrol setiap kebijakan pemerintah. Adanya kontrol masyarakat ini mendorong penyelenggaraan pemerintahan yang transparan dan akuntabel, sehingga membatasi terjadinya penyalahgunaan kewenangan dalam pemerintahan (Prabowo et al., 2014). Keberadaan 
Undang-Undang Keterbukaan Informasi Publik di era saat ini sangat penting dimiliki setiap lembaga pemerintahan, apalagi banyaknya kasus-kasus korupsi yang terjadi di negara kita, maka dengan adanya Undang-Undang Keterbukaan Informasi Publik ini lembaga pemerintah diwajibkan untuk memberikan informasi kepada masyarakat melalui media penyebaran informasi, sehingga masyarakat bisa melihat transparansi lembaga pemerintah atau bahkan masyarakat juga bisa berpartisipasi dalam penyusunan kebijakan publik. Dengan kebijakan ini tentunya diharapkan terciptanya pelayanan yang baik dan tata kelola pemerintahan yang bersih.

Mengacu pada UU KIP, informasi yang dihasilkan, disimpan, dikelola, dikirim, dan/atau diterima oleh suatu BP yang berkaitan dengan penyelenggara dan/atau BP lainnya yang sesuai dengan UU ini serta informasi lain, berkaitan dengan kepentingan publik. Pemerintah dapat memberikan pemahaman dan menyampaikan informasi terkait penyelenggaraan negara kepada masyarakat seperti suatu keputusan atau kebijakan publik yang dilakukan oleh BP. BP sebagai obyek keterbukaan informasi menjadi ujung tombak bagi terwujudnya pemerintahan yang transparan, akuntabel dan partisipatif. Salah satu elemen penting dalam mewujudkan penyelenggaraan negara yang terbuka adalah hak publik untuk memperoleh informasi sesuai dengan peraturan perundang-undangan. Hak atas informasi menjadi sangat penting karena semakin terbuka penyelenggaraan negara untuk diawasi publik, maka penyelenggaraan negara tersebut semakin dapat dipertanggungjawabkan. Hak setiap orang memperoleh informasi juga relevan untuk meningkatkan kualitas pelibatan masyarakat dalam proses pengambilan keputusan publik. Partisipasi atau pelibatan masyarakat tidak banyak berarti tanpa jaminan keterbukaan informasi publik (Ardipandanto, 2016).

\section{Demokrasi Deliberatif:}

Keterbukaan informasi tidak bisa dipisahkan dari konsep komunikasi yang dibangun oleh demokrasi deliberatif yang tidak lepas dari pengaruh Habermas yang meyakini bahwa rasio tetap menduduki jantung komunikasi manusia, yang baginya merupakan mesin utama emansipasi manusia (Ingram, 2011). Dalam bahasa lain disebutkan sebagai rekonstruksi teori tindakan komunikatif bidang politik untuk melengkapi kelemahan komplementer dalam liberalisme dan komunitarianisme (Devenney, 2004).

Menurut (Habermas, 2015), komunikasi merupakan ciri dasar kehidupan bersama manusia. Untuk mengembangkan teori tindakan komunikatif, Habermas membuat distinksi tegas antara kerja dan komunikasi sebagai dua yaitu komunikasi berkenaan dengan hubungan antar manusia demi terwujudnya saling pengertian diantara subjeksubjek yang berkomunikasi (West, 1996). Dalam bahasa Habermas sendiri, demokrasi deliberatif adalah suatu teori yang menerima diskursus rasional diantara para warga sebagai sumber legitimasi politik (Habermas, 2015)

Persyaratan demokrasi deliberatif menurut Norval mensyaratkan semua pihak untuk saling memperlakukan sebagai partner setara (equal), di mana setiap individu diberi ruang untuk bicara, saling mendengarkan, dan saling mempertanggungjawabkan posisi masing-masing (Critchley \& Marchart, 2012). Dalam demokrasi deliberatif para partisipan diberikan ruang public untuk bisa saling berinteraksi.

Ruang publik adalah sebuah ruang otonom yang berbeda dari negara dan pasar. Otonomi karena tidak hidup dari kekuasaan administratif maupun ekonomi kapitalistis, melainkan dari masyarakat sipil. Ruang publik politis ini bukanlah sebuah lembaga formal, melainkan ruang informal yang melaluinya para warga berkomunikasi. Ruang publik adalah arena dimana perdebatan publik terjadi. (Habermas, 2015) mengatakan bahwa ruang publik politis tidak lain daripada hakikat kondisi-kondisi komunikasi yang dengannya sebuah formasi opini dan aspirasi diskursif sebuah publik yang terdiri dari para warga negara dapat berlangsung (Hardiman, 2020). Ruang publik yang sehat harus memenuhi dua persyaratan, yakni bebas dan kritis. Bebas artinya setiap pihak dapat berbicara dimanapun, berkumpul, dan berpartisisipasi dalam debat politik dan kritis 
bermakna siapa saja boleh secara adil dan bertanggungjawab menyoroti proses-proses pengambilan keputusan (Reza, 2007)

Salah satu kunci utama dalam pengelolaan kebijakan yang berkualitas adalah tingginya intensitas partisipasi publik. Dialog dengan publik adalah kebenaran suatu kebijakan dan mengkado sarana utama untuk kebijakan yang siap digunakan (Sinambela, 2019). Dengan kata lain pengelolaan kebijakan publik sangat tergantung pada ada tidaknya ruang publik dan partisipasi publik.

Demokrasi deliberatif dalam masyarakat sipil, mempertemukan ide-ide, gagasangagasan dan usulan-usulan dalam kebijakan publik untuk mencapai kebijakan yang pro terhadap rakyat yang menurut bahasa Habermas sebagai diskursus yang bersifat inklusif, egaliter dan bebas dominasi, menghilangkan sekat-sekat birokrasi dalam berkomunikasi antar sesama warga masyarakat maupun dengan pemerintah (Badan Publik) yang dikenal dalam Undang-Undang Keterbukaan Informasi Publik, akan menghasilkan informasi yang dibutuhkan oleh masyarakat (Hardiman, 2020).

Pendekatan politik terhadap demokrasi deliberatif didasarkan pada teori politik yang normatif untuk mengevaluasi keberhasilah sebuah teori politik dengan jumlah kritik dan demokrasi deliberatif juga telah menarik perhatian warga negara, aktivis, organisasi reformasi, dan para pembuat keputusan di seluruh belahan dunia. Penerapan praktis dari ide-ide deliberatif dalam inovasi politik menyediakan sumber pelajaran yang kaya dari pengalaman yang dapat ditambahkan ke teori dan ilmu sosial (Curato, Nicole et all, 2017: 28-29).

Dalam membangun masyarakat yang demokrasi deliberatif memerlukan informasi kepada setiap warga negaranya tentang hak dan tanggung jawab mereka, bagaimana setiap warga negara dapat secara aktif terlibat dalam aktivitas pemerintahan dengan cara mengekspresikan suara mereka, meminta pertanggungjawaban yang berkuasa dan secara kolektif menentukan kebaikan bersama. Media memainkan peranan kunci dalam memenuhi tugas-tugas ini, terutama dalam masyarakat pasca-kolonial dalam transisi menuju demokrasi yang stabil. Namun peran mereka menghadapi serangkaian tantangan yang berbeda yaitu bagaimana komitmen dan norma media terhadap kepentingan publik ketika kepentingan dikemukakan secara luas, keberpihakan dan kekuasaan yang dimaknai sebagai kekuatan yang tidak material atau sebagai kebersamaan antara orang-orang, yang hanya dapat dihasilkan bersama untuk menyelesaikan beberapa tantangan praktik sosial demokratis, seperti yang terkait dengan peran media dalam masyarakat transisi (Tavernaro-Haidarian, 2020).

Sistem demokrasi deliberatif telah menjadi hal yang biasa bagi para sarjana untuk menghadirkan tujuan berbeda yang dicapai momen musyawarah atau komunikatif yang berbeda dalam sistem politik yang lebih luas. Menurut Owen dan Smith bahwa tipologi untuk membedakan antara praktik komunikatif musyawarah dan nonmusyawarah, saya berharap dapat membantu mengatasi 'bahaya kembar dari "peregangan konsep" dan "pelemahan kriteria"' yang muncul dalam beberapa aplikasi pendekatan sistem musyawarah yang menilai semua praktik politik sejauh mana mereka sengaja atau berkontribusi pada musyawarah. Mengabaikan praktik diskursif non-musyawarah berisiko memperluas konsep musyawarah dan membawa bahaya bahwa 'hampir setiap tindakan komunikatif dapat dikualifikasikan sebagai "musyawarah" (Beauvais, 2020).

\section{Kebijakan Publik:}

Dalam tataran keilmuan, kebijakan publik dapat dipandang sebagai suatu proses yang berkesinambungan dan saling terkait yang dilakukan pemerintah bersama stakeholder lain dalam mengatur, mengelola dan menyelesaikan berbagai jurusan publik, masalah publik. dan sumber daya yang ada untuk kepentingan bersama. Berbagai proses tersebut meliputi formulasi, implementasi dan evaluasi kebijakan (Mulyadi, 2016).

Anderson (2011:6) mendefinisikan sebagai a stable purposive course of action followed by an actor or set of actor in dealing with a problem or matter of concern. 
Thomas Dye (2011:1) mendefinisikan sebagai segala sesuatu yang dikerjakan pemerintah, mengapa mereka melakukan dan hasil yang membuat sebuah kehidupan bersama tampil berbeda (Sadhana, 2011) dengan tugas kebijakan publik adalah membangun rakyat, sehingga rakyat biasa dapat bekerja dengan luar biasa, dan menjadikan negara biasa menjadi negara yang luar biasa. Kebijakan publik dimaksudkan untuk memperkuat demokrasi dalam suatu negara yang mempunyai peraturan perundangundangan termasuk penguatan kebijakan publiknya, mengutip pendapat (Sadhana, 2011) yaitu:

"government is the relationship between government and citizens that enable public policies and programs to be formulated, emplemented and evaluated".

Pendapat lain tentang kebijakan publik adalah arah tindakan yang dilakukan pemerintah (Kismartini, 2019). Kebijakan publik adalah apa yang pejabat publik dalam pemerintahan, dan lebih luas lagi warga yang mereka wakili, pilih untuk dilakukan atau tidak dilakukan tentang masalah publik. Masalah publik mengacu pada kondisi yang secara luas dianggap tidak dapat diterima oleh publik dan oleh karena itu memerlukan intervensi. Masalah seperti degradasi lingkungan, akses yang tidak memadai ke layanan perawatan kesehatan, atau seperti yang disebutkan di atas, keselamatan konsumen di wahana taman hiburan dapat diatasi melalui tindakan pemerintah; tindakan pribadi, di mana individu atau perusahaan mengambil tanggung jawab; atau kombinasi keduanya. Dalam kasus tertentu, pilihan tergantung pada bagaimana publik mendefinisikan masalah dan pada sikap masyarakat yang berlaku tentang tindakan swasta dalam kaitannya dengan peran pemerintah (Kraft \& Furlong, 2019).

Menurut (Dunn, 2000) setiap kebijakan publik mencakup beberapa tahapan yang saling bergantung menurut urutan waktu: penyusunan agenda, formulasi kebijakan, adopsi kebijakan, implementasi kebijakan dan penilaian kebijakan (Dunn, 2000). Menurut (Winarno, 2002) kebijakan publik secara garis besar mencakup tahap-tahap perumusan masalah kebijakan, implementasi kebijakan dan evaluasi kebijakan. Definisi yang lain lebih nyata pada pencapaian tujuan nasional yang meletakkan kebijakan publik sebagai manajemen pencapaian tujuan nasional (Sadhana, 2011).

Kebijakan publik adalah apa yang pejabat publik lakukan dalam pemerintahan, dan lebih luas lagi warga yang mereka wakili, pilih untuk dilakukan atau tidak dilakukan tentang masalah publik. Masalah publik mengacu pada kondisi yang secara luas dianggap tidak dapat diterima oleh publik dan oleh karena itu memerlukan intervensi. Masalah seperti degradasi lingkungan, akses yang tidak memadai ke layanan perawatan kesehatan, atau seperti yang disebutkan di atas, keselamatan konsumen di wahana taman hiburan dapat diatasi melalui tindakan pemerintah; tindakan pribadi, di mana individu atau perusahaan mengambil tanggung jawab; atau kombinasi keduanya. Dalam kasus tertentu, pilihan tergantung pada bagaimana publik mendefinisikan masalah dan pada sikap masyarakat yang berlaku tentang tindakan swasta dalam kaitannya dengan peran pemerintah (Kraft \& Furlong, 2019)

Pengertian kebijakan publik mempunyai banyak tafsir dan makna, tetapi secara prinsip dan esensi adalah sama. Pandangan dan paradigma kebijakan publik sebagai sebuah ilmu mempunyai cara pandang tersendiri bagi sebagian ahli. Para ahli mengklasifikasian makna kebijakan publik ke dalam 4 sudut pandang, yaitu: Pertama, kebijakan sebagai keputusan. Beberapa makna/definisi mengenai kebijakan publik yang termasuk dalam sudut pandang ini. Thomas R. Dye dalam buku Kebijakan Publik Untuk Negara-negara Berkembang, yang ditulis oleh (Hayat, 2018) mendefinisikan bahwa kebijakan publik sebagai "Whatever governments choose to do or not to do", yaitu segala sesuatu atau apapun yang dipilih oleh pemerintah untuk dilakukan atau tidak dilakukan. Dye juga memaknai kebijakan publik sebagai suatu upaya untuk mengetahui apa sesungguhnya yang dilakukan oleh pemerintah, mengapa mereka melakukannya, dan apa yang menyebabkan mereka melakukannya secara berbeda-beda. Lebih lanjut, dikatakan 
bahwa apabila pemerintah memilih untuk melakukan suatu tindakan, maka tindakan tersebut harus memiliki tujuan.

Menurut Dody Hermana, dkk (2019) istilah Kebijakan Publik (Public Policy) dalam administrasi negara menjadi sangat populer karena ruang lingkupnya sangat luas menangani aneka ragam cakupan substantif, didalamnya terdapat suatu program untuk mencapai tujuan, nilai-nilai, dan praktek-praktek yang terarah, yang merupakan praktek sosial. Pada hakekatnya kebijakan merupakan kajian terhadap peraturan atau program dalam rangka mencapai tujuan tertentu. Kebijakan selalu dihubungkan dengan upaya penyelesaian masalah memuat tiga elemen, yaitu:

1. Identifikasi dan tujuan yang ingin dicapai.

2. Taktik atau strategi dari berbagai langkah untuk mencapai tujuan yang diinginkan.

3. Penyediaan berbagai input untuk memungkinkan pelaksanaan secara nyata dari taktik dan strategi.

Dari pendapat-pendapat tersebut dapat disimpulkan bahwa kebijakan publik memiliki ciri-ciri antara lain: 1) bersifat positif berupa tindakan-tindakan pemerintah untuk mengatasi masalah tertentu, 2) dibuat dan dilakukan oleh pemerintah, 3) perlu partisipasi publik, 4) didasari oleh suatu peraturan perundang- undangan dan bersifat memaksa, 5) mengatur kepentingan publik, dan 6) memerlukan sumber daya. Sementara itu kegiatan kebijakan publik meliputi tiga kegiatan pokok yaitu: 1) Perumusan Kebijakan Publik, 2) Implementasi Kebijakan Publik, dan 3) Evaluasi Kebijakan Publik.Dengan demikian kebijakan publik sebagai tindakan yang mempunyai tujuan tertentu yang diikuti dan dilaksanakan oleh seorang pelaku atau sekelompok pelaku guna memecahkan suatu masalah tertentu. Lebih lanjut Anderson dalam (Thoha \& Dharma, 1995), menyebutkan bahwa terdapat implikasi-implikasi dari adanya pengertian kebijakan publik tersebut, yaitu:

1. bahwa kebijakan publik itu selalu mempunyai tujuan tertentu atau merupakan tindakan yang berorientasi kepada tujuan.

2. bahwa kebijakan itu berisi tindakan-tindakan atau pola-pola tindakan pejabat-pejabat pemerintah.

3. bahwa kebijakan itu adalah merupakan apa yang benar-benar dilakukan pemerintah, jadi bukan merupakan apa yang pemerintah bermaksud akan melakukan sesuatu atau menyatakan akan melakukan sesuatu.

4. bahwa kebijakan publik itu bersifat positif dalam arti merupakan beberapa bentuk tindakan pemerintah mengenai suatu masalah tertentu atau bersifat negatif dalam arti merupakan keputusan pejabat pemerintah untuk tidak melakukan sesuatu.

5. bahwa kebijakan pemerintah setidak-tidaknya dalam arti yang penting didasarkan atau selalu dilandaskan pada peraturan perundang-undangan yang bersifat memaksa.

Dari pendapat-pendapat tersebut dapat disimpulkan bahwa kebijakan publik memiliki ciri-ciri antara lain: 1) bersifat positif berupa tindakan-tindakan pemerintah untuk mengatasi masalah tertentu, 2) dibuat dan dilakukan oleh pemerintah, 3) perlu partisipasi publik, 4) didasari oleh suatu peraturan perundang- undangan dan bersifat memaksa, 5) mengatur kepentingan publik, dan 6) memerlukan sumber daya. Sementara itu kegiatan kebijakan publik meliputi tiga kegiatan pokok yaitu: 1) Perumusan Kebijakan Publik, 2) Implementasi Kebijakan Publik, dan 3) Evaluasi Kebijakan Publik.

\section{Implementasi Kebijakan Publik:}

Setiap Badan Publik wajib mengimplementasikan Undang-Undang No. 14 Tahun 2008, tentang Keterbukaan Informasi Publik. Implementasi merupakan salah satu tahapan dari kebijakan publik yang diwujudkan dalam langkah nyata dari suatu peraturan perundangan. Menurut (Azmi, 2017), implementasi kebijakan publik adalah cara agar 
sebuah kebijakan dapat mencapai tunjuannya. Masalah implementasi kebijakan adalah hal yang berat, karena disini masalah-masalah yang kadang tidak dijumpai di dalam konsep muncul di lapangan karena keberhasilan ditentukan oleh rencana 20\%, implementasi $60 \%$ dan $20 \%$ sisanya adalah pengendalian.

Implementasi kebijakan sebagai suatu proses menurut pendapat Van Meter dan Van Horn dalam (Winarno, 2002), membatasi implementasi kebijakan sebagai tindakantindakan yang dilakukan oleh individu-individu (atau kelompok-kelompok) pemerintah maupun swasta yang diarahkan untuk mencapai tujuan-tujuan yang telah ditetapkan dalam keputusan-keputusan kebijakan sebelumnya. Tahap implementasi kebijakan mencakup usaha-usaha mengubah keputusan menjadi tindakan-tindakan operasional maupun usaha-usaha untuk mencapai perubahan-perubahan besar dan kecil. Tahap ini baru terjadi setelah undang-undang ditetapkan dan dana disediakan untuk membiayai implementasi kebijakan.

Implementasi kebijakan adalah suatu proses transformasi keputusan ke dalam tindakan nyata dalam rumusan kebijakan publik yang telah ditetapkan baik pada tingkat politik maupun administratif yang kemudian tahap berikutnya maka kebijakan itu akan diimplementasikan. Pemerintahan yang baik dan efektif apabila ada keinginan politik yang positif untuk mendukung imlementasi kebijakan yang telah ditetapkan. Berbagai temuan berkenaan pencapaian implementasi undang-undang dapat dipilahkan secara sederhana menjadi dua (Pratikno, 2012) yaitu: pengembangan kelembagaan, dan pencapaian substantif. Aspek substantif ini tersusun atas tiga indikator, yakni 1) ketersediaan media penyampai, 2) produk dan jenis informasi yang sudah dipublikkan, dan 3) kemudahan akses bagi publik untuk mendapatkan informasi tersebut. Peran pelaksana implementasi sangat menentukan terimplementasikannya suatu kebijakan sehingga pelaksana implementasi harus benar-benar memahami kebijakan yang akan dilaksanakan. Disamping itu faktor eksternal perlu diperhatikan pula untuk dapat mendukung kelancaran dalam implementasi kebijakan tersebut. Untuk mengetahui apa yang sebenarnya terjadi setelah suatu kebijakan dibuat dan dirumuskan adalah subyek implementasi kebijakan.

Penelitian tentang Partisipasi Warga dalam Implementasi Kebijakan Publik Cina dalam Big Data, bahwa di Big Data Age ditemukan bahwa dalam proses pelaksanaan kebijakan publik, badan eksekutif berpartisipasi dan mengawasi secara bersama-sama. Dengan demikian, efek implementasi tidak akan menyimpang dari efek yang diharapkan atau menghasilkan deviasi kecil yang kondusif bagi terwujudnya tujuan kebijakan publik. Tujuan kebijakan publik adalah memaksimalkan kepentingan sosial dan melindungi kepentingan sosial. Apakah tujuan kebijakan publik dapat memaksimalkan kepentingan publik tergantung pada apakah warga negara berpartisipasi dalam proses implementasi kebijakan publik dan kedalaman serta luasnya proses tersebut. Jika partisipasi warga dalam proses sangat positif, ini akan secara langsung mempengaruhi implementasi kebijakan publik atau ini merupakan peran pengawasan. Dalam proses implementasi kebijakan publik, sulit bagi semua subjek untuk memastikan bahwa tidak ada situasi "rent-seek". Setelah warga berpartisipasi, subjek pelaksanaan kebijakan publik akan diperkuat pengawasan eksternal, tidak menyimpang dari arah yang ditetapkan dalam proses pelaksanaan kebijakan publik, dan akan kondusif untuk mencapai tujuan subjek pelaksanaan kebijakan publik dengan lebih baik (Xiaodong et al., 2019).

Implementasi kebijakan merupakan bagian ilmu kebijakan. Dalam ranah implementasi kebijakan, salah satu definisi yang paling banyak disitas adalah pendapat Mazmanian and Sabatier yakni "the carrying out of a basic policy decision, usually incorporated in a statute but which can also take the form of important executive orders or court decisions" pelaksanaan keputusan kebijakan dasar, biasanya dimasukkan dalam undang-undang, tetapi yang juga dapat mengambil bentuk perintah eksekutif atau keputusan pengadilan yang penting. Implementasi fokus pada bagaimana seseorang dapat menghasilkan perubahan melalui intervensi tertentu (Signé, 2017). Implementasi kebijakan 
dimaknai sebagai pelaksanaan atau penerapan suatu kebijakan. Implementasi kebijakan adalah tahap pembuatan keputusan diantara pembentukan sebuah kebijakan, seperti halnya pasal-pasal sebuah undang-undang legislatif, pengeluaran sebuah peraturan eksekutif, pelolosan keputusan pengadilan, atau keluarnya standar peraturan dan konsekuensi dari kebijakan bagi masyarakat yang mempengaruhi beberapa aspek kehidupannya. Jika sebuah kebijakan diambil secara tepat, maka kemungkinan kegagalan pun masih bisa terjadi, jika proses implementasi tidak tepat, namun bahkan sebuah kebijakan yang brilian sekalipun jika diimplementasikan dengan buruk, bisa gagal untuk mencapai tujuan para perancangnya. Implementasi kebijakan publik dapat diartikan sebagai aktivitas penyelesaian atau pelaksanaan suatu kebijakan publik yang telah ditetapkan/disetujui dengan penggunaan sarana (alat) untuk mencapai tujuan kebijakan. Fungsi dan tujuan implementasi ialah untuk membentuk suatu hubungan yang memungkinkan tujuan-tujuan ataupun sasaran-sasaran kebijakan publik (politik) dapat diwujudkan sebagai "outcome" (hasil akhir) dari kegiatan yang dilakukan oleh pemerintah. Implementasi dapat disebut sebagai "policy delivery system". Kebijakan dibuat pada prinsipnya adalah untuk dilaksanakan atau diimplementasikan. Dengan harapan bahwa implementasi kebijakan itu sesuai dengan tujuan atau alasan kebijakan tersebut dibuat. Beberapa alasan yang mendasari bahwa suatu kebijakan harus diimplementasikan, menurut berbagai referensi adalah mengharapkan agar dapat ditunjukkan konfigurasi dan sinergi dari tiga variabel yang menentukan keberhasilan implementasi kebijakan, yakni hubungan segi tiga variabel kebijakan, organisasi, dan lingkungan kebijakan (Widuri, 2020).

\section{Model Implementasi Kebijakan:}

Model implementasi kebijakan perlu untuk menjelaskan proses implementasi kebijakan. Ada beberapa model implementasi kebijakan yang berkaitan dengan permasalahan penelitian diantaranya yang dikemukakan oleh Van Meter dan Van Horn (Winarno, 2002), menekankan pada variabel-variabel yang mempengaruhi keberhasilan dalam proses implementasi kebijakan yaitu: 1) ukuran dasar dan tujuan kebijakan, 2) sumber-sumber kebijakan, 3) komunikasi antar organisasi kegiatan-kegiatan pelaksanaan, 3) karakteristik badan-badan pelaksana, 4) kondisi-kondisi ekonomi, sosial dan politik, dan 5) kecenderungan pelaksana.

Ukuran-ukuran dasar dan tujuan-tujuan kebijakan berguna didalam menguraikan tujuan-tujuan keputusan kebijakan secara menyeluruh, hendaknya dirumuskan dengan jelas agar tujuan dapat tercapai dimana kejelasan rumusan standard dan tujuan kebijakan sangat menentukan kinerja kebijakan dari isi rumusan kebijakan tersebut. Dengan adanya petunjuk-petunjuk pelaksanaan yang ada dapat menjadi pegangan bagi pelaksana kebijakan sehingga tidak menyimpang dari tujuan yang sebenarnya.

Sumber-sumber kebijakan atau sumber daya diperlukan untuk mendukung kelancaran implementasi kebijakan secara efektif yang meliputi sumber daya manusia misalnya keahlian, dedikasi, kreatifitas, keaktifan dan sumber daya dana, sarana maupun prasarana. Komunikasi antar organisasi dan kegiatan-kegiatan pelaksanaan menyangkut kejelasan, ketepatan, konsistensi, dalam mengkomunikasikan ukuran-ukuran dan tujuan tersebut sehingga akan memudahkan pelaksana dalam pencapaian tujuan kebijakan. Dengan demikian keberhasilan implementasi memerlukan jalinan komunikasi yang baik. Komunikasi tersebut mencakup baik intern maupun ektern, yakni hubungan didalam lingkungan sistem politik dengan kelompok sasaran maupun antar organisasi. Karakteristik-karakteristik badan-badan pelaksana menyangkut norma-norma dan polapola hubungan yang terjadi berulang-ulang dalam badan-badan eksekutif yang mempunyai hubungan baik potensial maupun nyata dengan apa yang mereka miliki dengan menjalankan kebijakan, yang terdiri dari ciri-ciri struktur formal dari organisasiorganisasi dan atribut-atribut yang tidak formal dari personil mereka. Kondisi sosial, ekonomi, dan politik, adalah tersedianya sumber daya ekonomi yang dapat mendukung kelancaran implementasi kebijakan dan menyangkut lingkungan sosial dan politik 
(dukungan elit) yang mempengaruhi yurisdiksi atau organisasi dimana implementasi dilaksanakan. Kecenderungan pelaksana (implementor) menyangkut persepsi-persepsi pelaksana untuk mendukung atau menentang kebijakan. Tanpa adanya persepsi yang sama antara pelaksana dan pembuat keputusan akan menghambat bagi kelancaran implementasi kebijakan.

Model implementasi kebijakan yang sering terjadi selama ini adalah model "bottom-up" merupakan transmisi informasi yang sangat umum. Selain itu juga terdapat mode utama transmisi informasi yang lain adalah mode "top-down" di China, yang mentransfer informasi dari atas ke bawah. Manfaat dari pendekatan ini terbukti dengan sendirinya, tetapi juga banyak masalah. Ketika atasan pemerintah menyampaikan informasi kepada pemerintahan tingkat bawah, maka pemerintahan yang lebih rendah akan secara selektif mengirimkan informasi kepada bawahannya sendiri. Memilih informasi yang bermanfaat untuk tingkat mereka sendiri akan terus diteruskan kepada pemerintahan yang lebih rendah, tetapi informasi yang tidak menguntungkan bagi tingkat mereka sendiri tidak akan ditransmisikan atau transmisi selektif sesedikit mungkin. Model transfer "bottom-up" hanya menggantikan mode transfer "top-down". Partisipasi warga dalam proses implementasi kebijakan publik juga suatu bentuk umpan balik dari bawah ke atas, yang memungkinkan warga negara untuk merefleksikan penyimpangan yang timbul dari pelaksanaan kebijakan publik pada waktunya, sehingga pemerintah dapat merespon dengan tepat waktu. dan menyesuaikannya tepat waktu. Partisipasi warga dalam pelaksanaan kebijakan publik kondusif untuk implementasi model kebijakan publik "bottom-up". Partisipasi warga negara dalam implementasi kebijakan yang kondusif untuk memahami kepentingan dan kebutuhan publik pada waktunya, dan dapat meningkatkan kesadaran warga dan dukungan terhadap konten implementasi kebijakan publik, meningkatkan rasa percaya kepada pemerintah dapat secara aktif mempromosikan implementasi kebijakan publik, dan meningkatkan kinerja implementasi kebijakan publik. Partisipasi warga negara dalam proses implementasi kebijakan publik kondusif untuk menyuarakan kepentingannya sendiri, dan dapat memberikan nasehat kepada pembuat kebijakan pemerintah. Respon tepat waktu dari pejabat pemerintah pelaksana kebijakan publik kondusif untuk penegasan warga negara tentang pemerintah, staf pemerintah dan kebijakan publik. Respon tepat waktu dari praktisi kebijakan publik pemerintah kondusif untuk penegasan warga negara terhadap pemerintah, staf pemerintah dan kebijakan publik. Hal ini juga kondusif bagi efisiensi, keilmuan, demokrasi dan supremasi hukum pemerintahan dalam proses pengelolaan, dan kondusif bagi kepentingan semua pihak. Selain itu, dapat mendorong maksimalisasi kepentingan publik (Xiaodong et al., 2019).

Menurut (Supriati \& Pangalila, 2019), bahwa penerapan kebijakan publik yang merupakan salah satu kegiatan dalam proses kebijakan publik seringkali kontradiktif, padahal produk kebijakan mampu membatasi pembuat kebijakan itu sendiri. Oleh karena itu, implementasinya membutuhkan pemahaman yang mendalam tentang studi kebijakan publik. Dengan kata lain, konteks yang terkait dengan implementasi, terdiri dari beberapa kategori. Draf pertama, program dengan penjelasan tugas yang lengkap, rumusan tujuan yang tidak dikaburkan, serta penetapan capaian yang jelas terkait biaya dan waktu. Kedua, mengimplementasikan program dengan memanfaatkan struktur, personel, dana serta sumber daya lain, serta prosedur dan teknik yang benar. Ketiga, menyusun program yang sesuai, mengupayakan pengawasan secara dengan proses, teknik, operasi, dan kemampuan eksekutif yang berwenang untuk menafsirkan dan menggunakan kebijakan publik untuk mencapai dan memahami visi dan harapan yang diinginkan. Pandangan ini akan membantu peneliti lebih memahami kebijakan publik, meskipun telah dirumuskan dengan benar dalam pelaksanaannya, realisasinya menantang.

\section{Model Implementasi Kebijakan:}

Kebijakan mengarah pada implementasi dan aktualisasi model. Banyak faktor yang menentukan keberhasilan implementasi kebijakan, dan masing-masing saling 
berhubungan. Untuk memperdalam pemahaman tentang beberapa faktor yang terlibat, Model Merilee S. Grindle mendefinisikan teori implementasi sebagai proses politik dan administrasi yang didorong oleh isi kebijakan dan latar belakangnya. Ia juga mengklaim bahwa proses implementasi kebijakan dimulai setelah tujuan dan sasaran telah dikembangkan, program aksi digariskan, dan sejumlah cadangan uang yang dialokasikan untuk mencapai tujuan dan sasaran tersebut. Menurut (Supriati \& Pangalila, 2019) implementasi kebijakan adalah latihan yang diusulkan untuk melaksanakan suatu program sambil berkonsentrasi pada tiga tindakan utama; 1) Pengaturan, pembuatan atau pemindahan sumber daya, unit dan prosedur untuk membantu dalam berfungsinya program, 2) Interpretasi dan pemahaman program, 3) Fungsi, yang berkaitan dengan penyelenggaraan kegiatan konvensional yang melibatkan penataan barang dan jasa. Ini juga menegaskan sudut pandang bahwa mengubah, membatasi, dan mengaksesi adalah pendekatan penting dalam teknik implementasi.

Dari model yang dikemukakan oleh Van Meter dan Van Horn maka dapat disimpulkan bahwa ada banyak faktor yang mempengaruhi keberhasilan implementasi kebijakan. Untuk memenuhi ukuran dasar dan tujuan kebijakan, karakteristik, serta birokrasi pelaksana diperlukan adanya komunikasi yang tepat. Juga diperlukan adanya sumber daya meliputi sumber daya manusia dan sumber dana, sarana maupun prasarana agar kebijakan dapat terimplementasikan, serta tersedianya sumber daya ekonomi dan lingkungan sosial dan politik yang dapat mendukung keberhasilan implementasi kebijakan. Dalam penelitian ini mengambil model Van Meter dan Van Horn dengan satu variabel yang diambil yakni kondisi sosial, ekonomi dan politik yang diduga mempengaruhi keberhasilan implementasi kebijakan. Dengan pertimbangan variabel kondisi sosial ekonomi dan politik mempunyai relevansi dengan permasalahan penelitian yang ada yang terjadi di lingkungan masyarakat saat ini.

\section{KESIMPULAN}

Melalui proses, teknik, operasi, dan kemampuan eksekutif yang berwenang untuk menafsirkan dan menggunakan kebijakan publik untuk mencapai dan memahami visi dan harapan yang diinginkan. Pandangan ini akan membantu peneliti lebih memahami kebijakan publik, meskipun telah dirumuskan dengan benar dalam pelaksanaannya, realisasinya menantang.

Dalam rangka meningkatkan kepercayaan publik terhadap KPPU, perlu dilakukan pemberdayaan masyarakat persaingan usaha melalui advokasi kepada stakeholder, dan memperkuat jaringan sinergi dan komunikasi yang lebih intensif kepada Pemerintah Pusat dan Daerah. Secara substansi perlu dibuatkan website tersendiri tentang PPID serta pengaturan implementasi kebijakan keterbukaan informasi publik dalam peraturan internal KPPU, agar bisa dipahami dan diimplementasikan secara keseluruhan.

Program implementasi keterbukaan informasi publik harus menjadi bagian program PPID KPPU RI dalam memberikan dan meningkatkan pelayanan kepada masyarakat. Untuk itu diperlukan penyediaan anggaran PPID KPPU yang memadai dalam mendukung kegiatan keterbukaan informasi publik KPPU. Struktur organisasi perlu ditetapkan secara jelas disertai dukungan sumber daya manusia yang memiliki kapasitas yang memadai. Diperlukan Standar Layanan Informasi untuk mendukung implementasi keterbukaan informasi publik, juga diperlukan kegiatan Advokasi, Sosialisasi, dan Edukasi tentang Keterbukaan Informasi Publik guna menguatkan kapasitas sumber daya manusia yang ditugaskan di PPID, pimpinan Satuan Kerja serta seluruh pegawai di lingkungan KPPU RI. Tidak kalah pentingnya diperlukan adanya kegiatan monitoring dan evaluasi terhadap implementasi keterbukaan informasi publik KPPU RI, mendorong partisipasi stakeholder dalam penguatan implementasi keterbukaan 
informasi publik di KPPU RI. Selanjutnya, Bagian Humas perlu melakukan kegiatan monitoring dan evaluasi secara langsung dalam meningkatkan kualitas layanan informasi publik.

\section{BIBLIOGRAPHY}

Ardipandanto, A. (2016). Kelemahan Pelaksanaan PILPRES 2014: Sebuah Analisis. Jurnal Politica Dinamika Masalah Politik Dalam Negeri Dan Hubungan Internasional, 6(1).

Azmi, H. (2017). Implementasi Program Pelatihan Ex-Buruh Rokok Dari Penggunaan Dana Bagi Hasil Cukai Hasil Tembakau (Dbhcht) Kabupaten Kudus. Faculty of Social and Political Science.

Beauvais, E. (2020). Deliberation and Non-Deliberative Communication. Journal of Deliberative Democracy, 16(1).

Critchley, S., \& Marchart, O. (2012). Democratic decisions and the question of universality: rethinking recent approaches ALETTA NO RVAL. In Laclau (pp. 150-176). Routledge.

Devenney, M. (2004). Ethics and politics in contemporary theory between critical theory and post-Marxism. Routledge.

Dunn, W. N. (2000). Pengantar Analisis Kebijakan Publik (Terjemahan), Edisi Kedua. Yogyakarta: Gajah Mada.

Habermas, J. (2015). Between facts and norms: Contributions to a discourse theory of law and democracy. John Wiley \& Sons.

Hardiman, F. B. (2020). Demokrasi Deliberatif" Menimbang Negara Hukum, dan Ruang Publik dalam Teori Diskursus Jurgen Habermas. Kanisius.

Hayat, H. (2018). Buku Kebijakan Publik. Universitas Islam Malang Malang, Indonesia.

Hermansyah, I., Rahman, R., \& Suherman, M. (2018). Pengaruh Akuntabilitas dan Transparansi Terhadap Kualitas Pelayanan Publik (Survei Pada Dinas Daerah Kotatasikmalaya)Hermansyah, I., Rahman, R., \& Suherman, M. (2018). Pengaruh Akuntabilitas dan Transparansi Terhadap Kualitas Pelayanan Publik (Survei Pada. Jurnal Akuntansi, 13(1), 21-29.

Ingram, D. (2011). Habermas: Introduction and analysis. Cornell University Press.

Kismartini, K. (2019). Analisis Kebijakan Publik (Kerangka Dasar).

Kraft, M. E., \& Furlong, S. R. (2019). Public policy: Politics, analysis, and alternatives. Cq Press.

Maddox, B. (2007). From Models to Mechanisms: Multi-Disciplinary Perspectives on Literacy and Development.

Mulyadi, D. (2016). Studi Kebijakan Publik dan Pelayanan Publik: Konsep dan Aplikasi Proses Kebijakan Publik Berbasis Analisis Bukti Untuk Pelayanan Publik. 
Prabowo, R. D., Manar, D. G., \& Adhi, S. (2014). Implementasi undang-undang keterbukaan informasi publik dalam upaya mewujudkan good governance (kajian tiga badan publik: Bappeda, Dpkad Dan Dinas Pendidikan Kota Semarang). Journal of Politic and Government Studies, 3(3), 187-195.

Pratikno. (2012). Kajian implementasi keterbukaan informasi dalam pemerintahan lokal: pasca Undang-Undang nomor 14 tahun 2008. Fisipol UGM.

Reza, A. A. (2007). Melampaui Negara Hukum Klasik. kanisius.

Sadhana, K. (2011). Realitas Kebijakan Publik.

Signé, L. (2017). Policy implementation-A synthesis of the study of policy implementation and the causes of policy failure. OPC Policy Center, PP-17, 3, 922.

Sinambela, L. P. (2019). Reformasi pelayanan publik: teori, Kebijakan dan implementasi.

Supriati, A., \& Pangalila, T. (2019). Transparency Policy Implementation Process Manado City Government.

Tavernaro-Haidarian, L. (2020). Deliberative Theory and African Philosophy: The Future of Deliberation in Transitional Societies. Journal of Deliberative Democracy, 16(1).

Thoha, M., \& Dharma, A. (1995). Birokrasi Indonesia Dalam Era Globalisasi. Pusdiklat Pegawai Depdikbud [Pusat Pendidikan dan Pelatihan Pegawai ....

West, D. (1996). An introduction to continental philosophy.

Wibawa, K. C. S. (2019). Urgensi Keterbukaan Informasi dalam Pelayanan Publik sebagai Upaya Mewujudkan Tata Kelola Pemerintahan yang Baik. Adm. Law Gov. $J, 2(2), 218-234$.

Widuri, N. R. (2020). Studi Implementasi Kebijakan Work From Home pada Pustakawan di LIPI. Media Pustakawan, 27(3), 168-177.

Winarno. (2002). Teori dan proses kebijakan publik. Media Pressindo.

Xiaodong, L., Xiaoping, L., \& Feng, F. (2019). Research on Citizen Participation in the Implementation of Public Policy in Big Data Age※. Journal of Physics: Conference Series, 1168(3), 32013.

(C) 2021 by the authors. Submitted for possible open access publication under the 